\title{
MOLECULAR DIAGNOSTICS OF DUCHENNE/BECKER MUSCULAR DYSTROPHY PATIENTS BY MULTIPLEX LIGATION-DEPENDENT PROBE AMPLIFICATION ANALYSIS AND DIRECT SEQUENCING
}

Todorova $\mathrm{A}^{1, *}$, Guergueltcheva $\mathrm{V}^{2}$, Genova $\mathrm{J}^{3}$, Mihaylova $\mathrm{V}^{2}$, Todorov $\mathrm{T}^{1}$, Tchamova $\mathrm{T}^{2}$, Georgieva B ${ }^{1}$, Kremensky I ${ }^{4}$, Tournev I, ${ }^{2,5}$ Mitev $\mathrm{V}^{1}$

*Corresponding Author: Albena Todorova, Department of Chemistry and Biochemistry, Medical University Sofia, 2 "Zdrave" str., Sofia 1431, Bulgaria; Tel./Fax: +359-2-9530715; E-mail: todorova_albena@abv.bg

\begin{abstract}
Duchenne/Becker muscular dystrophy (DMD/ $\mathrm{BMD}$ ), the most common X-linked muscular dystrophy is caused by mutations in the enormously large DMD gene. We screened this gene in 51 unrelated Bulgarian DMD/BMD patients and four families with no living index patient available, by multiplex ligation-dependent probe amplification (MLPA) analysis, which is a powerful tool for detecting deletion/duplication along the DMD gene. This, in combination with direct sequencing, characterized the mutation in all patients, which comprised 42 deletions (82\%), six duplications (12\%) and three point mutations $(6 \%)$, and precisely determined all deletion/duplication borders. In all the families with no living index patient available, deletions were

1 Department of Chemistry and Biochemistry, Sofia Medical University, Sofia, Bulgaria

2 Clinic of Neurology, Alexandrovska Hospital, Sofia Medical University, Sofia, Bulgaria

3 Genetic Medico-Diagnostic Laboratory "Genica", Sofia, Bulgaria

4 National Genetic Laboratory, Hospital of Obstetrics and Gynecology, Sofia Medical University, Sofia, Bulgaria

5 Department of Cognitive Science and Psychology, New Bulgarian University, Sofia, Bulgaria
\end{abstract}

detected by direct analysis on the patients' mothers and sisters, proving the value of MLPA for carrier status determination.

Key words: Duchenne/Becker muscular dystrophy (DMB/BMD), DMD gene, Dystrophin, Deletions, Duplications, Point mutations, Multiplex ligation-dependent probe amplification (MLPA) analysis

\section{INTRODUCTION}

Duchenne/Becker muscular dystrophy (DMD/ BMD; OMIM\#310200; 300376), the most common $\mathrm{X}$-linked muscular dystrophy, is caused by mutations in the enormously large DMD gene $(2.4 \mathrm{Mb}$; 79 coding exons). About $60 \%$ of the cases are due to deletions of one or more exons, $\sim 20 \%$ to duplications of one or more exons [1], and in $10 \%$ to point mutations of different type and location [1]. So far, the deletions have been mainly screened on the hot-spot regions by standard multiplex polymerase chain reaction (mPCR) [2,3]. Precise deletion borders have rarely been clarified by analysis of single exons, and then only for research rather than a diagnostic purpose $[4,5]$.

Recently, MLPA (multiplex ligation-dependent probe amplification) analysis [6] was successfully applied in the study of the DMD gene and resolved many complications of routine diagnostic approaches that are offered to $\mathrm{DMD} / \mathrm{BMD}$ families. 
Although not yet approved for diagnostic purposes, MLPA has been broadly applied for analyzing different genes [6]. However, it has been accepted as a standard in analysis of DMD/BMD patients and in preparing them for future gene therapy, and is required for inclusion in the Treat-NMD Network [7]. Here we present our results and experience in use of MLPA/direct sequencing for molecular analysis of the DMD gene in Bulgaria.

\section{MATERIALS AND METHODS}

Patients. Fifty-one patients and four families with no living index patient available were analyzed by MLPA/ direct sequencing. All patients were diagnosed clinically only on the basis of clinical symptoms, family history, electromyography (EMG) data and creatine kinase levels. In some, the result of muscular biopsy was also available. Thirty-six patients were severely affected, diagnosed as DMD, 14 had BMD and one patient was considered to represent an intermediate form (IMD). The affected members of the four families with no living index patient were suspected to be severely affected (there was one affected patient in each family).

Method. DNA samples were obtained from peripheral blood, using a DNA extraction kit (QIAamp DNA Mini Kit, QIAGEN, Hilden, Germany). Multiplex PCR of 18 exons for deletions detection along the deletion hot-spot was performed by the classical protocols of Chamberlain et al. [2] and Beggs et al. [3].

The SALSA MLPA P034/P035 (MRC-Holland, Amsterdam, The Netherlands) kit was used in accordance with the manufacturer's instructions [6]. Fifty to 200 ng of DNA were diluted with TE (Tris/ EDTA) (1 M Tris, 0.5M EDTA, pH 8.0) buffer to a volume of $5 \mu \mathrm{L}$. The diluted samples were subjected to hybridization with the DMD gene-specific probes for all 79 exons and to 13 control probes (along $\mathrm{Y}, \mathrm{Xq}$ and $\mathrm{Xp}$ chromosome regions) situated in both sets $\mathrm{P} 034$ and $\mathrm{P} 035$ [6], at $60^{\circ} \mathrm{C}$ overnight. The hybridized probes were ligated with a specific ligase mix, provided by the manufacturer. The final step represents PCR amplification of the ligated fragment products. The PCR buffer, PCR primers 6-FAM (6-carboxyfluorescein) labeled, the enzyme dilution buffer and the polymerase were provided in the kit.
The PCR products obtained were analyzed on an ABI PRISM ${ }^{\mathrm{TM}} 310$ genetic analyzer (Applied Biosystems, Foster City, CA, USA) in the presence of ROX500 size standard (Applied Biosystems). Each patient sample was analyzed simultaneously with at least two normal male samples. In order to assess copy number changes (duplications) in comparison to the normal controls, MLPA data interpretation was performed by MLPA software - Coffalyser [6].

Sequencing. The DNA from patients who tested negative by MLPA were sequenced for the entire coding sequence of the DMD gene, including exon/ intron borders. Each exon was amplified by primers, designed for sequencing in our laboratory (the primer sequence is available upon request). The PCR product was purified by PCR Product Pre-Sequencing Kit [United States Biochemicals (USB); Affymetryx Inc., Santa Clara, CA, USA] and sequenced by the BigDye Terminator Cycle Sequencing Kit v.3.1 (Applied Biosystems). The sequenced sample were subjected to a standard ethanol precipitation. The pellet was air-dried and kept at room temperature in the dark. Before run, the pellet was resuspended in $13 \mu \mathrm{L}$ Hi-Di Formamide (Applied Biosystems) and loaded into the ABI PRISM ${ }^{\text {TM }} 310$ genetic analyzer (Applied Biosystems). Sequencing results were interpreted by Sequence Scanner v. 1 (Applied Biosystems).

\section{RESULTS AND DISCUSSION}

The mutations we detected and clinical data are listed in Tables 1a and 1b. Some of these patients were reported in our previous paper [8]. The creatine kinase levels were highly elevated in all cases, with the exception of creatine kinase levels in handicapped patients, where the destroyed muscle leads to creatine kinase level normalization. The main group of patients started walking later than normal children (after 12 months). In two cases: deletion patient \#32 and duplication patient \#2, a serious delay in starting to walk was registered at around or after second year of age. The duplication patient \#2 had very severe symptoms with an early involvement of limbs, limb-girdle and neck muscles and fast disease progression.

The early symptoms in all patients have been very similar: walking on toes, difficulties in climbing stairs, running, getting up. Family history (the 
Table 1. Mutations detected in Bulgarian DMD/BMD patients and four families with no living DMD patients (DMD: Duchenne muscular dystrophy; BMD: Becker muscular dystrophy; IMD: intermediate muscular dystrophy; n.d.: no data.).

\begin{tabular}{|c|c|c|c|c|c|c|}
\hline \multirow[t]{2}{*}{ Diagnosis } & \multirow{2}{*}{$\begin{array}{l}\text { Mutations } \\
\text { a) DELETIONS }\end{array}$} & \multirow{2}{*}{$\begin{array}{c}\text { Creatine } \\
\text { Kinase } \\
\end{array}$} & \multicolumn{3}{|c|}{ Clinical Symptoms } & \multirow{2}{*}{$\begin{array}{l}\text { Family } \\
\text { History }\end{array}$} \\
\hline & & & $\begin{array}{l}\text { First Walked } \\
\text { at (months): }\end{array}$ & $\begin{array}{l}\text { First Symptoms } \\
\text { at (years): }\end{array}$ & Special Clinical Findings & \\
\hline 1. BMD & $\begin{array}{l}\text { ex45ex48del>c.6439-?_.7098+?del } \\
\text { in-frame }\end{array}$ & high & n.d. & n.d. & n.d. & no \\
\hline 2. DMD & $\begin{array}{l}\text { ex53ex54del>c.7661-?_8027+?del } \\
\text { out-of-frame }\end{array}$ & high & 14 & 3 & wheelchair bound & yes \\
\hline 3. DMD & $\begin{array}{l}\text { ex48ex52del>c.6913-?_7098+?del } \\
\text { out-of-frame }\end{array}$ & 1238 & 14 & 3 & $\begin{array}{l}\text { wheelchair bound, absent tendon reflexes in lower } \\
\text { limbs, contractures }\end{array}$ & no \\
\hline 4. BMD & $\begin{array}{l}\text { ex45ex48del>c.6439-?_7098+?del } \\
\text { in-frame }\end{array}$ & n.d. & 12 & 10 & $\begin{array}{l}\text { able to walk (age 33), difficulties in walking and } \\
\text { climbing stairs }\end{array}$ & yes \\
\hline 5. BMD & $\begin{array}{l}\text { ex45ex48del>c.6439-?_7098+?del } \\
\text { in-frame }\end{array}$ & 1664 & 14 & 12 & able to walk (age 21) & no \\
\hline 6. DMD & $\begin{array}{l}\text { ex79del>c.11047-?_22064+?del } \\
\text { does not encode to a functional protein? }\end{array}$ & 14390 & 13 & 6 & muscle hyppotonia, profound lordosis & no \\
\hline 7. DMD & $\begin{array}{l}\text { ex49ex52del>.c.7099-?_7660+?del } \\
\text { out-of-frame }\end{array}$ & 931 & 13 & 3.5 & $\begin{array}{l}\text { wheelchair bound, contractures, absent reflexes in } \\
\text { lower limbs }\end{array}$ & no \\
\hline 8. BMD & $\begin{array}{l}\text { ex45ex48del }>c .6439-? .7098+? d e l \\
\text { in-frame }\end{array}$ & 4845 & 12 & 12 & able to walk (age 23), difficulties in climbing stairs & no \\
\hline 9. DMD & $\begin{array}{l}\text { ex46ex50del>c.6616-?_7309+?del } \\
\text { out-of-frame }\end{array}$ & 15600 & 18 & $<2$ & wheelchair bound, contractures, scoliosis & no \\
\hline 10. BMD & $\begin{array}{l}\text { ex45ex53del>c.6439-?_. } 7872+\text { ?del } \\
\text { in-frame }\end{array}$ & 413 & 12 & 11 & able to walk (age 19) & no \\
\hline 11. DMD & $\begin{array}{l}\text { ex55del>c.8028-? } 8217+? \text { del } \\
\text { out-of-frame }\end{array}$ & 5979 & 13 & 3 & n.d. & no \\
\hline 12. DMD & ex58del>c.8548-?_8668+?del & 14548 & 14 & 5 & $\begin{array}{l}\text { wheelchair bound, scapula alatae, lumbal lordosis, } \\
\text { contractures of Achilles tendons }\end{array}$ & no \\
\hline 13. DMD & $\begin{array}{l}\text { ex46ex50del>c.6615-?_7309+?del } \\
\text { out-of-frame }\end{array}$ & 6000 & 14 & 3 & $\begin{array}{l}\text { able to walk (age } 10) \text {, contractures, scapula alatae, } \\
\text { absent patella reflexes }\end{array}$ & no \\
\hline 14. IMD & $\begin{array}{l}\text { ex49ex50del>c.7099-?_7309+?del } \\
\text { out-0f-frame }\end{array}$ & 9212 & 13 & 9 & $\begin{array}{l}\text { able to walk (age 17), pronounced lordosis, scapula } \\
\text { alatae, diminished patellar reflexes }\end{array}$ & no \\
\hline 15. DMD & $\begin{array}{l}\text { ex18ex37del>c.2169-?_5325+?del } \\
\text { out-of-frame }\end{array}$ & 13462 & n.d. & 6 & $\begin{array}{l}\text { Wheelchair bound, contractures, reduced tendon } \\
\text { reflexes in lower limbs }\end{array}$ & no \\
\hline 16. DMD & $\begin{array}{l}\text { ex46ex50del>c.6615-?.7409+?del } \\
\text { out-of-frame }\end{array}$ & 12000 & 16 & 4 & $\begin{array}{l}\text { wadling gait, pronounced lorsosis, hyporeflexia, } \\
\text { contractures }\end{array}$ & no \\
\hline 17. BMD & $\begin{array}{l}\text { ex03ex07del>c.94-?_649+?del } \\
\text { out-of-frame }\end{array}$ & 2355 & 12 & 10 & $\begin{array}{l}\text { able to walk (age 18), contractures, muscle } \\
\text { hypotonia, absent patellar reflexes }\end{array}$ & no \\
\hline 18. BMD & $\begin{array}{l}\text { ex45ex47del>c.6439-?_6912+?del } \\
\text { in-frame }\end{array}$ & 7979 & 12 & 11 & $\begin{array}{l}\text { able to walk (age 19), at age } 15 \text { myocardial } \\
\text { infarction, no muscle involvement at this age, } \\
\text { active in sports }\end{array}$ & no \\
\hline 19. DMD & $\begin{array}{l}\text { ex46ex50del>c.6615-?_7309+?del } \\
\text { out-of-frame }\end{array}$ & 9319 & 14 & $<2$ & $\begin{array}{l}\text { able to walk (age 13), pronounced lordosis, scapula } \\
\text { alatae, absent patellar reflexes, contractures }\end{array}$ & no \\
\hline 20. BMD & $\begin{array}{l}\text { ex45ex47del>c.6439-?_6912+?del } \\
\text { in-frame }\end{array}$ & 2733 & 12 & 11 & $\begin{array}{l}\text { able to walk (age 20), difficulties in walking and } \\
\text { climbing stairs }\end{array}$ & no \\
\hline 21. DMD & $\begin{array}{l}\text { ex51del>c.7310-? } 7542+? \text { del } \\
\text { out-of-frame }\end{array}$ & 11670 & 12 & 2 & wheelchair bound, hypotonia, hyporeflexia & no \\
\hline
\end{tabular}


Table 1 continue

\begin{tabular}{|c|c|c|c|c|c|c|}
\hline Diagnosis & Mutations & Creatine & & & linical Symptoms & Family \\
\hline 22. BMD & $\begin{array}{l}\text { ex45ex47del>c.6439-?_6912+?del } \\
\text { in-frame }\end{array}$ & 1758 & n.d. & 8 & $\begin{array}{l}\text { able to walk (age 35), pronounced lordosis, absent } \\
\text { patellar reflexes }\end{array}$ & yes \\
\hline 23. BMD & $\begin{array}{l}\text { ex45ex47del>c.6439-?_6912+?del } \\
\text { in-frame }\end{array}$ & 12000 & 12 & 11 & wheelchair bount, elbow contractures & no \\
\hline 24. DMD & $\begin{array}{l}\text { ex46ex55del>c.6615-?_8217+?del } \\
\text { out-of-frame }\end{array}$ & 2310 & 14 & 7 & $\begin{array}{l}\text { wheelchair bound, lower limb areflexia, scoliosis, } \\
\text { contractures }\end{array}$ & no \\
\hline 25. DMD & $\begin{array}{l}\text { ex45ex50del>c.6439-?_7309+?del } \\
\text { out-of-frame }\end{array}$ & 9191 & 12 & 4 & $\begin{array}{l}\text { able to walk (age 7), diminished patellar reflexes, } \\
\text { absent ankle reflexes, scapula alatae, pronounced } \\
\text { lordosis }\end{array}$ & yes \\
\hline 26. DMD & $\begin{array}{l}\text { ex08ex11del>c.650-?_1331+?del } \\
\text { out-of-frame }\end{array}$ & 18352 & 12 & 2 & $\begin{array}{l}\text { able to walk (age 10), scapula alatae, pronounced } \\
\text { lordosis, contractures, diminished patellar reflexes }\end{array}$ & no \\
\hline 27. DMD & $\begin{array}{l}\text { ex44del>c.6291-? } 6438+? \text { del } \\
\text { out-0f-frame }\end{array}$ & 19670 & 13 & 6 & $\begin{array}{l}\text { able to walk (age 9), diminished reflexes in lower } \\
\text { limbs, contractures }\end{array}$ & no \\
\hline 28. DMD & $\begin{array}{l}\text { ex08ex09del>c.650-? } 9900+? \text { del } \\
\text { out-of-frame }\end{array}$ & 14228 & 14 & 5 & able to walk (age 10), scapula alatae, contractures & no \\
\hline 29. DMD & $\begin{array}{l}\text { ex45ex79del>c.6439-?_(*2691_?)del } \\
\text { unexpected problem? }\end{array}$ & 1919 & 13 & 3 & $\begin{array}{l}\text { unable to walk independently, able to sit } \\
\text { independently, muscle hypotonia }\end{array}$ & no \\
\hline 30. BMD & $\begin{array}{l}\text { ex03ex07del?c.94-?_649+?del } \\
\text { out-of-frame }\end{array}$ & 2602 & 13 & 5 & $\begin{array}{l}\text { unable to walk independently, able to sit } \\
\text { independently, pronounced lordosis, diminished or } \\
\text { absent reflexes }\end{array}$ & no \\
\hline 31. DMD & $\begin{array}{l}\text { ex45del>c.6439-?_6614+?del } \\
\text { out-0f-frame }\end{array}$ & 298 & 18 & 4 & $\begin{array}{l}\text { wheelchair bound, absent reflexes in lower limbs, } \\
\text { scoliosis, contractures }\end{array}$ & no \\
\hline 32. DMD & $\begin{array}{l}\text { ex53del>c.7661-?_7872+?del } \\
\text { out-0f-frame }\end{array}$ & 13182 & 20 & 4 & able to walk (age 5), contractures & yes \\
\hline 33. DMD & $\begin{array}{l}\text { ex45ex54del>c.6439-?_8027+?del } \\
\text { out-of-frame }\end{array}$ & 15395 & 14 & 3 & able to walk (age 5), lordosis & no \\
\hline 34. DMD & $\begin{array}{l}\text { ex45ex53del>c.6439-?_7872+?del } \\
\text { in-frame }\end{array}$ & 22394 & n.d. & 3 & Able to walk (age 8), scapula alatae & yes \\
\hline 35. BMD & $\begin{array}{l}\text { ex45ex47del>c.6439-?_6912+?del } \\
\text { in-frame }\end{array}$ & 1240 & n.d. & 12 & able to walk (age 28) & no \\
\hline 36. DMD & $\begin{array}{l}\text { ex42ex45del>c.5932-?_6614+?del } \\
\text { out-of-frame }\end{array}$ & high & 14 & 2 & n.d. & No \\
\hline 37. DMD & $\begin{array}{l}\text { ex44del>c.6291-?_6438+?del } \\
\text { out-0f-frame }\end{array}$ & 12460 & 14 & 2 & muscle hypotonia & no \\
\hline 38. DMD & $\begin{array}{l}\text { ex46ex50del>c.6615-?_7309+?del } \\
\text { out-of-frame }\end{array}$ & 3982 & 14 & 2 & n.d. & No \\
\hline 39. DMD & $\begin{array}{l}\text { ex44del>c.6291-?_6438+?del } \\
\text { out-0f-frame }\end{array}$ & 2280 & 14 & 3 & profound lumbal lordosis, scapula alatae & no \\
\hline 40. DMD & $\begin{array}{l}\text { ex16ex17del>c.1813-?_2168+?del } \\
\text { out-of-frame }\end{array}$ & high & 15 & 3 & wheelchair bound & yes \\
\hline 41. BMD & $\begin{array}{l}\text { ex45ex48del>c.6439-?_7098+?del } \\
\text { in-frame }\end{array}$ & 800 & 12 & 13 & muscle hypotonia & no \\
\hline 42. DMD & $\begin{array}{l}\text { ex45ex52del>c.6439-?_7660+?del } \\
\text { out-of-frame }\end{array}$ & 420 & 14 & 3 & wheelchair bound & yes \\
\hline
\end{tabular}


Table 1 continue

\begin{tabular}{|c|c|c|c|c|c|c|}
\hline Diagnosis & Mutations & Creatine & \multicolumn{3}{|r|}{ Clinical Symptoms } & \multirow{2}{*}{$\begin{array}{l}\text { Family } \\
\text { History }\end{array}$} \\
\hline & DUPLICATIONS & & & & & \\
\hline 1. DMD & $\begin{array}{l}\text { ex48ex50dup>C.6913-?_7309+?dup } \\
\text { out-0f-frame }\end{array}$ & 4500 & 14 & 3 & wheelchair bound, lordosis & yes \\
\hline 2. DMD & $\begin{array}{l}\text { ex02ex33dup>c.32-?_4674+?dup } \\
\text { out-of-frame }\end{array}$ & 1521 & 29 & 1 & $\begin{array}{l}\text { cannot sit up, twist, or keep the head upright at } 10 \\
\text { months of age }\end{array}$ & no \\
\hline 3. DMD & $\begin{array}{l}\text { ex08ex11dup>c.650-?__1331+?dup } \\
\text { out-of-frame }\end{array}$ & 9000 & 15 & 5 & walks on toes, cannot climb stairs alone & no \\
\hline 4. BMD & $\begin{array}{l}\text { ex13ex40dup>c.1483-?_5739+?dup } \\
\text { in-frame }\end{array}$ & 1107 & 12 & 12 & profound lordosis & yes \\
\hline 5. DMD & $\begin{array}{l}\text { ex02ex10dup>c.32-?_1149+?dup } \\
\text { out-of-frame }\end{array}$ & 409 & 15 & $<2$ & $\begin{array}{l}\text { wheelchair bound, hyporeflexia, contractures, } \\
\text { scoliosis }\end{array}$ & yes \\
\hline \multirow[t]{2}{*}{ 6. DMD } & $\begin{array}{l}\text { ex51dup>c.7310-?_7542+dup } \\
\text { out-of-frame }\end{array}$ & 4500 & 16 & 3 & wheelchair bound & yes \\
\hline & POINT MUTATIONS & & & & & \\
\hline 1. DMD & exon 7 c.583C $>T$, p.Arg195X & 12000 & 16 & 2 & hyporeflexia in Achilles tendons and knees & no \\
\hline 2. DMD & exon 23 c.2991C>G, p.Tyr997X & 17100 & 13 & 3 & died at age 17 & no \\
\hline \multirow[t]{2}{*}{ 3. DMD } & exon 59 c.8776C $>$ T, p.Gln2926X & 9000 & 15 & 2 & hyporeflexia in lower limbs & yes \\
\hline & b) NO INDEX PATIENT AVAILABLE & & & & & \\
\hline 1. DMD & $\begin{array}{l}\text { ex46ex52del>c.6913-? } 7660+? d \text { del } \\
\text { out-of-frame }\end{array}$ & - & - & - & - & no \\
\hline 2. DMD & $\begin{array}{l}\text { ex48ex50del>c.6913-?_7309+?del } \\
\text { out-of-frame }\end{array}$ & - & - & - & - & no \\
\hline 3. DMD & $\begin{array}{l}\text { ex45ex50del>c.6439-?_7309+?del } \\
\text { out-of-frame }\end{array}$ & - & - & - & - & no \\
\hline 4. DMD & $\begin{array}{l}\text { ex49ex54del>c.7099-?_8027+?del } \\
\text { out-of-frame }\end{array}$ & - & - & - & - & no \\
\hline
\end{tabular}

presence of other affected family members) was positive in 13 cases.

The deletion patient \#23 had been clinically diagnosed as Emery-Dreifuss muscular dystrophy (OMIM\#181350; OMIM\#310300). The precise diagnosis of BMD was established during the present study.

Of interest is the deletion of the very last exon of the DMD gene (exon 79), detected in deletion patient \#6. It is not clear where the deletion ends, but the clinical picture was compatible with DMD phenotype (early onset and fast progression). Deletion patient \#29 also had a deletion covering exon 79. He was also severely affected with a fast disease progression. A similar mutation has been described earlier in a BMD patient as a part of a contiguous gene deletion syndrome [9].

Two duplications of exons 2-33 and 13-40 (duplication patients \#2 and \#4) cover more than onethird of the gene sequence, and result in DMD and
BMD phenotypes, respectively. Most probably, the duplication situated close to the N-terminus of the dystrophin is associated with a severe phenotype, while the one in the rod-domain leads to the BMD phenotype [8].

Some patients were pre-screened for deletions in the DMD gene by a standard multiplex set of primers. In deletion patient $\# 14$ the deletion of exons 49-50 was detected in this way, but the family requested confirmation with an alternative method. In several cases the deletions were detected by mPCR, but deletion borders were not precisely determined, or carrier status determination in these families required MLPA. In deletion patients \#37 and \#39, the deletion of exon 44 was not detected by multiplex PCR (most probably because of PCR unspecificity or contamination) and they were not considered as deletions. A number of index patients were classified as unknown mutations after mPCR.

The MLPA analysis/direct sequencing charac- 

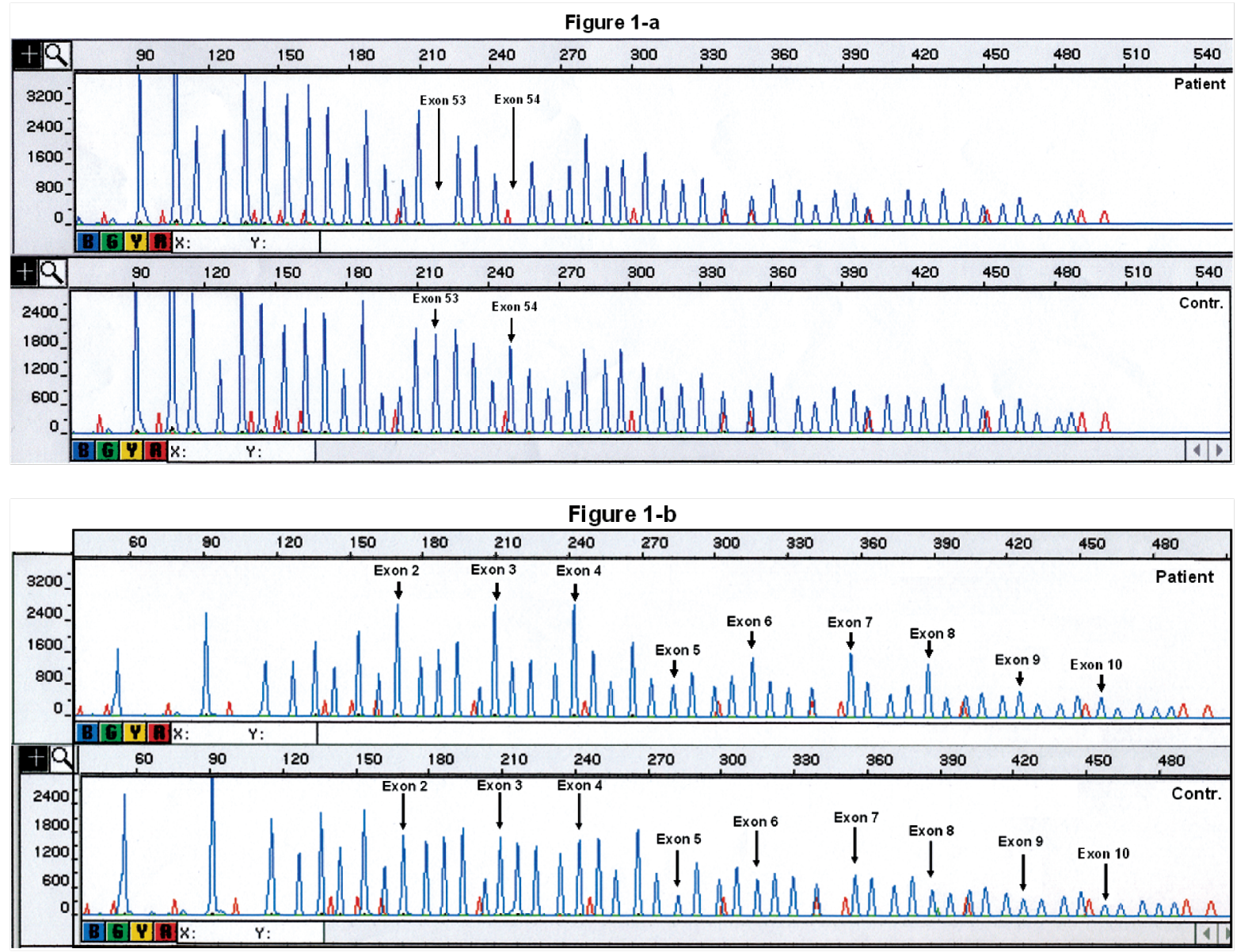

Figure 1. Capillary electrophoresis pattern (a) in patient \#2 with deletion of exons 53-54 and (b) in patient \#5 with duplication of exons 2-10, compared to a control sample. The deleted or duplicated fragments are indicated by arrows.

terized mutation in all cases, which comprised 42 deletions (82\%), six duplications (12\%) and three point mutations $(6 \%)$ (see Table 1a). In addition, this analysis in the four families with no living index patient revealed deletions in all families of dead patients diagnosed with DMD, using the DNA samples of their mothers and sisters (see Table 1b).

All deletion/duplication borders were precisely determined by this method as required for adequate gene therapy in the future. The deletion and duplication electrophoretic profiles are presented on Figure $1 \mathrm{a}$ and $1 \mathrm{~b}$. All deletions were confirmed by PCR amplification.

In our hands, the combination of the MLPA test with direct sequencing of the entire DMD gene, proved to be a powerful diagnostic approach in DMD/BMD families. In point mutation patient \#2 only exon 23 was missing on the MLPA electropherogram. The single amplification of exon 23 showed its presence in the patient, but the point mutation c.2991C $>$ G, p.Tyr997X was detected by sequencing of the exon [8]. Point mutation patients \#1 and \#3 tested negative by MLPA, but sequencing of the entire coding sequence of the DMD gene revealed the nonsense mutations c. $8776 \mathrm{C}>\mathrm{T}$, p.Gln2926X and c.583C $>$ T, p.Arg195X, respectively [8].

The classical mPCR of 18 exons in the deletion hot-spot region of the DMD gene [2,3] could detect 36 deletions in the present sample $(86 \%$ of deletions), 15 of which (42\%) were only partial, with no clear deletion borders. The mPCR could only detect deletions, and it is applicable only when the index patient is available for study. Moreover, the presented MLPA analysis was successful not only in all the patients tested, but also in all four families with no index patient. We identified four deletions in these families (see Table 1b); all four mothers were deletion carriers, one sister was genetically proved to 
be a carrier and two were not carriers. The MLPA data is easily interpreted also for direct carrier status determination.

The application of the most recent genetic tests in our routine diagnostic studies, gave us the possibility to genetically clarify a number of Bulgarian DMD/BMD patients. A national web site for clinically and genetically well described neuromuscular cases is available [10], according to the requirements of the Treat-NMD Network.

\section{ACKNOWLEDGMENTS}

A fellowship of the Alexander von Humboldt Foundation to Assistant Professor Albena Todorova is gratefully acknowledged. The study was supported by grant No. VU-L-317/2007 funded by the Bulgarian Ministry of Education and Science. Some of the patients are part of another study supported by grant No. 24/2008 from the Sofia Medical University, Sofia, Bulgaria.

\section{REFERENCES}

1. DMD Genetic Therapy Group, Leiden muscular dystrophy pages. 1997; retrieved from http:// www.dmd.nl.

2. Chamberlain JS, Gibbs RA, Ranier JE, Nguyen PN, Caskey CT. Deletion screening of the Duchenne muscular dystrophy locus via multiplex DNA amplification. Nucleic Acids Res 1988; 16(23): 11141-11156.
3. Beggs AH, Koenig M, Boyce FM, Kunkel LM. Detection of $98 \%$ of DMD/BMD gene deletions by polymerase chain reaction. Hum Genet 1990; 86(1): 45-48.

4. Danieli GA, Mioni F, Mueller CR, Vitiello L, Mostacciuolo ML, Grimm T. Patterns of deletions of the dystrophin gene in different European populations. Hum Genet 1993; 91(4): 342-346.

5. Todorova A, Bronzova J, Miorin M, Rosa M, Kremensky I, Danieli GA. Mutation analysis in Duchenne and Becker muscular dystrophy patients from Bulgaria shows a peculiar distribution of breakpoints by intron. Am J Med Genet 1996; 65(1): 40-43.

6. MRC Holland, Amsterdam (http://www. mlpa.com).

7. Treat-NMD Neuromuscular Network, advancing diagnosis, care and treatment for people with neuromuscular diseases around the world (http://www.treat-nmd.eu).

8. Todorova A, Todorov T, Georgieva B, Lukova M, Guergueltcheva, V, Kremensky I, Mitev V. MLPA analysis/complete sequencing of the DMD gene in a group of Bulgarian Duchenne/Becker muscular dystrophy patients. Neuromuscul Disord 2008; 18(8): 667-670.

9. Greener MJ, Sewry CA, Muntoni F, Roberts RG. The 3'-untranslated region of the dystrophin gene - conservation and consequences of loss. Eur J Hum Genet 2002; 10(7): 413-420.

10. Bulgarian Neuromuscular Dystrophy Society (http://www.nmd-bg.com). 